\title{
Performance Evaluation Study on Software and Information Technology Service Listed Companies
}

\author{
Bingzhi $\mathrm{Li}^{1}$ \\ ${ }^{1}$ College of Economics and Management, Nanjing University of Aeronautics and Astronautics, Nanjing, China \\ Correspondence: Bingzhi Li, College of Economics and Management, Nanjing University of Aeronautics and \\ Astronautics, Nanjing, Jiangsu, China. Tel: 86-132-1801-5153. E-mail: 2256691943@qq.com
}

Received: November 2, 2018

Accepted: November 30, $2018 \quad$ Online Published: December 15, 2018

doi:10.5539/ijef.v11n1p76

URL: https://doi.org/10.5539/ijef.v11n1p76

\begin{abstract}
The development of software and information technology service is not only related to the promotion of information industry competitiveness, but also closely related to the adjustment and optimization of industrial structure and even the development of national economy. In recent years, software and information technology services have developed well. However, there are still some problems such as weak international competitiveness, weak innovation ability and unbalanced talent structure, etc. This paper builds the performance evaluation index system of software and information technology service enterprises from five perspectives of profitability, operation ability, debt paying ability, development ability and innovation ability. To evaluate the performance of listed companies in software and information technology services by combining TOPSIS and grey relational degree method to balance the performance of the enterprise and discover the problems in the development of the enterprise in time.
\end{abstract}

Keywords: software and information technology service, performance evaluation, innovation ability, software copyright, TOPSIS, grey correlation degree

\section{Introduction}

Software and information technology service changed the way of life, work and economic development dramatically since it appeared not very long. Software and information technology service industry is characterized by fierce competitiveness, fast replacement, high scientific and technological content, high added value of products, wide application range and low resource consumption, etc. The government issued $<$ Circular of the state council on the issuance of several policies to further encourage the development of the software industry and the integrated circuit industry $\rangle,\langle$ Decision of the state council on accelerating the cultivation and development of strategic emerging industries $>$, < The 12th five-year plan for software and information technology service > and < Strategic planning for software and information technology services 2016-2020> and so on to provide policy support in aspects of taxation, import and export preferences, R\&D investment, talent cultivation, investment and financing and intellectual property protection, etc. Software and information technology services were given new development goals during the 13th five-year plan period, its business revenue will exceed 8 trillion RMB in 2020, with an average annual growth rate of more than $13 \%$, accounting for more than $30 \%$ of the information industry, over 20 enterprises with 10 billion revenue, 5 to 8 hundred billion revenue enterprises. Although the government has clearly set development goals, the realization of these goals still depends on the development of enterprises, and the division and refinement of these goals and plans into the daily operation of software and information technology service enterprises to measure the performance of an enterprise, find problems in its development in time, and help the enterprise better understand its position in similar enterprises.

Jianbin, Yanli, and Kaibo (2014) proposed knowledge cooperation performance evaluation system and believed that knowledge cooperation should not only pay attention to the efficiency of knowledge cooperation, but also pay attention to the appreciation of intellectual capital and social capital. Therefore, this paper evaluates the effectiveness and efficiency of knowledge cooperation. The effectiveness of knowledge cooperation mainly measures the increment of social capital and the increment of intellectual capital. The efficiency of knowledge cooperation mainly measures the timeliness and accuracy of knowledge. Mingook and Sungjoo (2016) established the evaluation system of internal technological capability of energy enterprises from three aspects: 
enterprise competitiveness, enterprise organizational competitiveness and enterprise technological competitiveness. Enterprise competitiveness includes evaluation of human resources and continuous learning. Enterprise organizational competitiveness includes infrastructure construction and evaluation of organizational process. Enterprise technical performance includes the evaluation of technical level and technical assets. Peipei, Sen, Haoran, et al. (2017) constructed the performance evaluation system of power grid enterprises from three aspects of economy, society and environment. The economy aspect includes total labor productivity, asset-liability ratio and net assets income rate. Social aspect includes reliability of power supply and efficiency in handling customer complaints. Environmental aspect includes the procurement rate of new energy generation and sulfur hexafluoride emissions. Song and Shanying (2015) conduct enterprise performance evaluation from internal performance and external performance. Internal performance includes financial performance, business process performance and learning and growth performance, among which financial performance includes profitability, debt paying ability, operation ability and development potential, business process performance includes technical innovation and internal operation, learning and growth performance includes employee quality, customer loyalty and teamwork level. External performance includes customer and social performance, and customer performance includes customer satisfaction and after-sales service level. Social aspect performance includes public relations and social responsibility. Rough set and wavelet neural network are selected for evaluation. In this paper, rough sets and fuzzy mathematics are used to preprocess and simplify the index system. The input dimensions of wavelet neural network are reduced. The parameters of the neural network are determined by the algorithm of step by step test and iterative reduction, and the comprehensive evaluation value of enterprise performance evaluation is finally obtained. Rui (2015) pointed out that the enterprise performance evaluation under the new normal will find some changes: More emphasis on innovation drive, highlight enterprise management features and advantages, pay attention to the evaluation of effective betting opportunities, focus on the evaluation of the quality of human capital, evaluate the rationality of the leverage ratio, include green and low-carbon development in the evaluation, evaluate the resolve overcapacity, reasonably determine the weight of the evaluation. Baiji and Nan used DEA method to evaluate the performance of media listed companies, taking shareholder equity, total responsibility and salary as input indicators, and considering the company's market value, price-to-earnings ratio and price-to-book ratio as output indicators. Bingqiu (2016) used fuzzy analytic hierarchy process to evaluate the performance of new third board enterprises. The evaluation index is divided into financial index and non-financial index, among of which financial index evaluates profitability, solvency, operating capacity and growth capacity, while non-financial index evaluates human capital, technical capital, managerial capital and relational capital. Yong (2017) conducted static and dynamic analysis of the comprehensive performance of the listed companies in the press and publication industry. Static analysis is made from three aspects of market size, operation scale and asset scale, and dynamic analysis is made from the financial status and growth. Through the horizontal and vertical comparison, this paper analyzes the business performance of enterprises after entering the new normal economy and analyzes the problems. Zhixu and Yu (2017) used EVA index to compare the performance of China's new energy listed companies horizontally and vertically. EVA is an absolute index, which cannot be used to compare enterprises of different sizes. So this paper uses unit capital economy additional value as complement, that is, divide the economic added value of a certain period by the average amount of capital. The performance evaluation of software and information technology service enterprises is less in the literature at home and abroad. In addition, the evaluation index system designed by most of the literature of performance evaluation is similar and not specific to the characteristics of the industry. The current situation of software and information technology service companies with high competitiveness and rapid product upgrading determines that enterprises must pay attention to the characteristics of innovation ability. The measure of innovation capacity of software and information technology services companies cannot be measured by patent numbers as in other industries. Software copyright is also an important index to measure its innovation ability and determine its competitiveness. Therefore, it is necessary to design a reasonable, objective and comprehensive performance evaluation system based on the characteristics of information technology service industry.

\section{The Construction of Performance Evaluation Index System of Listed Companies in Software and Information Technology Services}

This paper constructs the performance evaluation index system of software and information technology service enterprises from the perspectives of profitability, operation ability, debt paying ability, development ability and innovation ability, shown as Table 1 the performance evaluation index system of listed companies in software and information technology services. 
Table 1 . The performance evaluation index system of listed companies in software and information technology services

\begin{tabular}{|c|c|c|}
\hline First grade indexes & Second grade indexes & Computational formula \\
\hline \multirow{7}{*}{ Profitability } & Operation revenue gross profit rate & (Operation revenue -Operation costs)/ Operation revenue \\
\hline & & Operating profit/Operating expenses \\
\hline & Operating expenses profit margin & $\begin{array}{l}\text { Among: Operating expenses=Operation costs }+ \text { Taxes and additional+ } \\
\text { Handling expense+ Financial expense+ Selling expenses } \\
\text { (Total profits + Interest expense)/Average assets }\end{array}$ \\
\hline & Return on total asset & Among: Replace interest expenses with financial expenses \\
\hline & & Average assets $=($ Starting assets + Ending assets $) / 2$ \\
\hline & Net assets income rate & $\begin{array}{l}\text { Net profit attributable to the owner of the parent company/ Average } \\
\text { ownership attributable to the owner of the parent company }\end{array}$ \\
\hline & Sales profit ratio & $\begin{array}{l}\text { Cash received from selling goods and providing services/ operation } \\
\text { revenue }\end{array}$ \\
\hline \multirow{7}{*}{ Operation ability } & Assets cash recovery rate & Net cash flow from operating activities/ Average assets \\
\hline & & Operation revenue/ Average receivables \\
\hline & Turnover of account receivable & $\begin{array}{l}\text { Among: Average receivables }=(\text { Starting receivables }+ \text { Ending } \\
\text { receivables }) / 2\end{array}$ \\
\hline & & Accounts receivable $=$ Accounts receivable + Notes receivable \\
\hline & & Operation revenue/ Average current assets \\
\hline & Current assets turnover & $\begin{array}{l}\text { Among: Average current assets }=(\text { Starting current assets }+ \text { Ending } \\
\text { current assets }) / 2\end{array}$ \\
\hline & Total assets turnover & Operation revenue/ Average assets \\
\hline \multirow{5}{*}{ Debt paying ability, } & & Quick assets/ Current liabilities \\
\hline & Quick ratio & Among: Quick assets $=$ Current assets- Stock \\
\hline & Asset-liability ratio & Total liability/ Total assets \\
\hline & & Net cash flow from operating activities/ Average current liabilities \\
\hline & Cash flow ratio & $\begin{array}{l}\text { Among: Average current liabilities }=(\text { Starting current liabilities }+ \text { Ending } \\
\text { current liabilities }) / 2\end{array}$ \\
\hline \multirow{3}{*}{$\begin{array}{l}\text { Development } \\
\text { ability }\end{array}$} & Operation revenue growth rate & $\begin{array}{l}\text { (Ending operation revenue- Starting operation revenue)/ absolute value } \\
\text { of starting operation revenue }\end{array}$ \\
\hline & Total profit growth rate & $\begin{array}{l}\text { (Total ending profit - Total starting profit)/ absolute value of total starting } \\
\text { profit }\end{array}$ \\
\hline & Total assets growth rate & $\begin{array}{l}\text { (Total ending assets- Total starting assets)/ absolute value of total starting } \\
\text { assets }\end{array}$ \\
\hline \multirow{3}{*}{ Innovation ability } & R\&D expenditure proportion & R\&D expenditure/ Operation revenue \\
\hline & R\&D personnel proportion & Number of researchers/ Total number of staffs \\
\hline & $\begin{array}{l}\text { Cumulative quantity of technical } \\
\text { assets }\end{array}$ & $\begin{array}{l}\text { Number of software copyrights+ Number of authorized invention patents } \\
\text { (recent three years) }\end{array}$ \\
\hline
\end{tabular}

\section{Selection of Performance Evaluation Methods for Listed Companies in Software and Information Technology Service}

\subsection{Entropy Weight Method}

Firstly, entropy weight method is used to calculate the weight of each evaluation index in this paper. The basic idea of entropy weight method is that if the gap between the data is large, the information contained is large and the weight should be large. The calculation steps are as follows:

\section{(1) Standardization}

When evaluation index $x_{i j}$ is forward,

$$
x_{i j}^{*}=\frac{x_{i j}-x_{\min }}{x_{\max }-x_{\min }}
$$

When evaluation index $x_{i j}$ is backward,

$$
x_{i j}^{*}=\frac{x_{\max }-x_{i j}}{x_{\max }-x_{\min }}
$$


When evaluation index $x_{i j}$ is neutral,

$$
x_{i j}^{*}=\left\{\begin{array}{l}
1-\frac{p-x_{i j}}{\max \left(\left|p-x_{\min }\right|,\left|x_{\max }-p\right|\right)}, x_{i j} \leq p \\
1-\frac{x_{i j}-p}{\max \left(\left|p-x_{\min }\right||| x_{\max }-p \mid\right)}, x_{i j}>p
\end{array}\right.
$$

Thereinto, $x_{i j}$ represents the $j$ index value of $i$ company, $x_{i j}^{*}$ is the value after standardization, $p$ means the ideal value for this index.

(2) Determine the proportion

$$
Y_{i j}=\frac{x_{i j}^{*}}{\sum_{i=1}^{m} x_{i j}^{*}}
$$

(3) Calculate entropy

$$
e_{j}=-\frac{1}{\ln m} \sum_{i=1}^{m} Y_{i j} \ln Y_{i j}
$$

Thereinto, when $Y_{i j}=0$, assume $Y_{i j} \ln Y_{i j}=0$

(4) Calculate variable coefficient

(5) Calculate weight, weight vector is

$$
\begin{gathered}
\gamma_{j}=1-e_{j} \\
v=\left\{v_{1}, v_{2}, \ldots, v_{n}\right\} \\
v_{j}=\frac{\gamma_{j}}{\sum_{j=1}^{n} \gamma_{j}}
\end{gathered}
$$

\subsection{Gray Correlation Method Based on TOPSIS}

(1) Calculate the weighted standard matrix

$$
U=\left(u_{i j}\right)_{m \times n}=\left(v_{j} x_{i j}^{*}\right)=\left[\begin{array}{cccc}
u_{11} & u_{12} & \cdots & u_{1 n} \\
u_{21} & u_{22} & \cdots & u_{2 n} \\
\vdots & \vdots & \cdots & \vdots \\
u_{m 1} & u_{m 2} & \cdots & u_{m n}
\end{array}\right]
$$

Thereinto, $U$ is weighted standard matrix, $u_{m n}$ is the $n$ index weighted value after standard of $m$ company.

(2) Determine the positive and negative ideal solution

Positive ideal solution is

$$
U^{+}=\left\{u_{01}^{+}, u_{02}^{+}, \cdots, u_{0 n}^{+}\right\}
$$

Negative ideal solution is

$$
U^{-}=\left\{u_{01}^{-}, u_{02}^{-}, \cdots, u_{0 n}^{-}\right\}
$$

Thereinto, $U^{+}$and $U^{-}$is the matrix of positive and negative ideal solution. Positive ideal solution $u_{0 j}^{+}$and negative ideal solution $u_{0 j}^{-}$is the maximum and minimum of each indicator respectively.

(3) Calculate grey correlation degree

$$
\begin{gathered}
\rho_{i j}^{+}=\frac{\min _{1 \leq j \leq n 1 \leq i \leq m}\left(\left|u_{0 j}^{+}-u_{i j}\right|\right)+\xi \max _{1 \leq j \leq n 1 \leq i \leq m} \max _{0 j}\left(\left|u_{o j}^{+}-u_{i j}\right|\right)}{\left|u_{0 j}^{+}-u_{i j}\right|+\xi \max _{1 \leq j \leq n 1 \leq i \leq m}\left(\left|u_{0 j}^{+}-u_{i j}\right|\right)} \\
P_{i}^{+}=\frac{\sum_{j=1}^{n} \rho_{i j}^{+}}{n}
\end{gathered}
$$

Thereinto, $\rho_{i j}^{+}$is the grey correlation coefficient between $j$ index value of $i$ company and positive ideal solution, $\xi$ is resolution coefficient, general is $0.5, P_{i}^{+}$is the grey correlation coefficient between $i$ company and positive ideal solution. $P_{i}^{-}$, the grey correlation degree between $i$ company and negative ideal solution, is obtained in the similar way.

(4) Calculate relative closeness coefficient 


$$
C_{i}=\frac{P_{i}^{+}}{P_{i}^{-}+P_{i}^{+}},(i=1,2, \ldots m)
$$

Among, $C_{i}$ is the relative closeness coefficient of $i$ company

\section{Case Analysis of Performance Evaluation for Listed Companies in Software and Information Technology Services}

\subsection{Sample Selection}

This paper selects listed companies in "Industry classification results of listed companies in the fourth quarter of 2015", "Industry classification results of listed companies in the fourth quarter of 2016" and "Industry classification results of listed companies in the fourth quarter of 2017" published by China Securities Regulatory Commission, and remove the listed companies by ST, *ST, enter ST or enter *ST, companies with audit report opinions for 2017 are not " unqualified opinion", companies that just went public in 2015, data incomplete and data abnormal companies, companies which are divided into information technology services listed but its core competitiveness is not such a company. Finally, 102 listed companies were selected as samples.

\subsection{Data Pre-Processing}

Data of software copyright and authorized invention patents in 2015-2017 are collected the names of subsidiaries disclosed in the annual reports of listed companies in 2017, and then the data information of the parent company and all subsidiaries are inquired in the enterprise search website. Except quick ratio and asset-liability ratio, other indicators are positive indicators. The appropriate values of the quick ratio and asset-liability ratio are selected from the excellent values of the computer service and software industry in the <Enterprise Performance Evaluation Standard> [79] published by the financial supervision and assessment bureau of State-owned Assets Supervision and Administration Commission in 2018. The index value is standardized according to formula (2.3).

\subsection{Determine Weights}

According to the formula of entropy weight method, the weights of performance evaluation indexes of software and information technology service companies are calculated, as Table 2 Weight of performance evaluation index for listed companies in software and information technology service

Table 2. Weight of performance evaluation index for listed companies in software and information technology service

\begin{tabular}{ccc}
\hline First grade indexes & Second grade indexes & Weight \\
\hline \multirow{3}{*}{ Profitability } & Operation revenue gross profit rate & 0.0845 \\
& Operating expenses profit margin & 0.0050 \\
& Return on total asset & 0.0115 \\
& Net assets income rate & 0.0195 \\
Operation ability & Sales profit ratio & 0.0365 \\
& Assets cash recovery rate & 0.0215 \\
& Turnover of account receivable & 0.1562 \\
Debt paying ability, & Current assets turnover & 0.0552 \\
& Total assets turnover & 0.0629 \\
Development ability & Quick ratio & 0.0074 \\
& Asset-liability ratio & 0.0434 \\
Innovation ability & Cash flow ratio & 0.0152 \\
& Operation revenue growth rate & 0.1313 \\
& Total profit growth rate & 0.0071 \\
& Total assets growth rate & 0.0435 \\
& R\&D expenditure proportion & 0.0840 \\
\hline
\end{tabular}

\subsection{Determine the Positive and Negative Ideal Solution}

The maximum and minimum weighted standard values of 102 sample companies were selected as the positive and negative ideal solutions for each index, as Table 3 Positive negative ideal solution of listed companies in software and information technology service. 
Table 3. Positive and negative ideal solution of listed companies in software and information technology service

\begin{tabular}{|c|c|c|c|c|c|}
\hline Index & $\begin{array}{c}\text { Positive ideal } \\
\text { solutions } \\
\end{array}$ & $\begin{array}{c}\text { Negative ideal } \\
\text { solutions }\end{array}$ & Index & $\begin{array}{c}\text { Positive ideal } \\
\text { solutions } \\
\end{array}$ & $\begin{array}{c}\text { Negative ideal } \\
\text { solutions }\end{array}$ \\
\hline Operation revenue gross profit rate & 0.0845 & 0.0000 & Quick ratio & 0.0074 & 0.0000 \\
\hline Operating expenses profit margin & 0.0050 & 0.0000 & Asset-liability ratio & 0.0434 & 0.0000 \\
\hline Return on total asset & 0.0115 & 0.0000 & Cash flow ratio & 0.0152 & 0.0000 \\
\hline Net assets income rate & 0.0195 & 0.0000 & Operation revenue growth rate & 0.1313 & 0.0000 \\
\hline Sales profit ratio & 0.0365 & 0.0000 & Total profit growth rate & 0.0071 & 0.0000 \\
\hline Assets cash recovery rate & 0.0215 & 0.0000 & Total assets growth rate & 0.0435 & 0.0000 \\
\hline Accounts receivable turnover & 0.1562 & 0.0000 & $\mathrm{R} \& \mathrm{D}$ density & 0.0840 & 0.0000 \\
\hline Current asset turnover & 0.0552 & 0.0000 & $\mathrm{R} \& \mathrm{D}$ personnel proportion & 0.0418 & 0.0000 \\
\hline Total assets turnover & 0.0629 & 0.0000 & $\begin{array}{c}\text { Cumulative quantity of technical } \\
\text { assets }\end{array}$ & 0.1734 & 0.0000 \\
\hline
\end{tabular}

\subsection{Performance Evaluation Results of Listed Companies in Software and Information Technology Service}

According to the formula (9), (10) and (11), the relative closeness coefficient of each listed companies is calculated, and then the performance ranking of listed companies is conducted according to the relative closeness coefficient, the higher the relative closeness, the better the performance. Because there are too many sample companies, only the top 5 listed companies are shown in Table 4 Performance evaluation results of listed companies in software and information technology service

Table 4. Performance evaluation results of listed companies in software and information technology service

\begin{tabular}{|c|c|c|}
\hline Stock code & Performance ranking & - $\quad$ Relative closeness coefficient \\
\hline 002410 & 1 & 0.5037 \\
\hline 600406 & 2 & 0.4977 \\
\hline 002280 & 3 & 0.4897 \\
\hline 002405 & 4 & 0.4854 \\
\hline 600588 & 5 & 0.4808 \\
\hline
\end{tabular}

\section{Comprehensive Performance Analysis of Listed Companies in Software and Information Technology Service}

\subsection{Analyze the Index Weight}

From the final weight value, it can be seen that the accounts receivable turnover rate, operation revenue growth rate and the cumulative quantity of technical assets have a great weight, and the weight value of the accumulated quantity of technical assets of innovation ability is the largest. It shows that in these three aspects, there are big differences between enterprises, which should be paid attention to by enterprises. The maximum weight of innovation capability is also consistent with the current situation that software and information technology service companies should pay attention to innovation and improve innovation capability.

\subsection{Analyze the Top 5 Performance Ranking of Listed Companies}

In order to better analyze the listed companies, this paper counts the ranking of each evaluation index of each company, as Table 5 Index ranking status of top 5 performance ranking of listed companies.

Table 5. Index ranking status of top 5 performance ranking of listed companies

\begin{tabular}{|c|c|c|c|c|c|}
\hline Performance ranking & 1 & 2 & 3 & 4 & 5 \\
\hline Stock code Index & 002410 & 600406 & 002280 & 002405 & 600588 \\
\hline Operation revenue gross profit rate & 1 & 69 & 98 & 4 & 7 \\
\hline Operating expenses profit margin & 14 & 26 & 90 & 47 & 58 \\
\hline Return on total asset & 5 & 2 & 79 & 77 & 40 \\
\hline Net assets income rate & 5 & 1 & 91 & 64 & 54 \\
\hline Sales profit ratio & 12 & 59 & 7 & 77 & 36 \\
\hline Assets cash recovery rate & 3 & 7 & 98 & 31 & 6 \\
\hline Accounts receivable turnover & 1 & 67 & 7 & 37 & 31 \\
\hline Current asset turnover & 25 & 26 & 1 & 70 & 36 \\
\hline
\end{tabular}




\begin{tabular}{|c|c|c|c|c|c|}
\hline Total assets turnover & 39 & 14 & 3 & 79 & 42 \\
\hline Quick ratio & 66 & 36 & 96 & 59 & 8 \\
\hline Asset-liability ratio & 26 & 46 & 15 & 63 & 34 \\
\hline Cash flow ratio & 3 & 35 & 98 & 33 & 30 \\
\hline Operation revenue growth rate & 60 & 3 & 1 & 26 & 40 \\
\hline Total profit growth rate & 50 & 5 & 91 & 15 & 8 \\
\hline Total assets growth rate & 67 & 1 & 5 & 2 & 48 \\
\hline R\&D density & 4 & 73 & 100 & 1 & 15 \\
\hline R \& D personnel proportion & 55 & 76 & 56 & 25 & 66 \\
\hline Cumulative quantity of technical assets & 25 & 1 & 82 & 31 & 4 \\
\hline
\end{tabular}

It can be seen from the ranking of each performance indicator that enterprise performance is the result of the comprehensive influence of each indicator. From the top 5 performance companies, each company has the outstanding aspect, also has the weak performance. No company excels in everything. The first listed company has excellent profitability but poor development capability. The second listed company did well in development, but poorly in R\&D investment. The third listed company performed well in operating capacity, but poorly in profitability and innovation. The fourth listed company performed well in terms of development ability and innovation ability, but poorly in terms of operation. The fifth listed company has excellent performance in terms of the cumulative number of technical assets and good performance in all aspects.

\section{Conclusion}

Accounts receivable turnover, operation revenue growth rate and accumulative quantity of technical assets are the aspect that the enterprise pays special attention in development in the terms of performance evaluation process of listed companies in the software and information technology services. In addition, enterprises should pay attention to innovation, the output and commercialization process of innovation, and strengthen the protection of their own intellectual property rights. Finally, the enterprise should develop in an all-round way in the process of operation, don't attend to one thing and lose another.

\section{References}

Chen, J., Guo, Y., \& Xu, K. (2014). Value added from knowledge collaboration: Convergence of intellectual capital and social capital. https://doi.org/10.14257/ijunesst.2014.7.2.02

Lee, M., \& Lee, S. (2016). Evaluating Internal Technological Capabilities in Energy Companies. https://doi.org/10.3390/en9030145

Li, B., \& Zhou, N. (2016). Evaluation of market value management performance of coal listed companies. https://doi.org/10.13546/j.cnki.tjyjc.2016.04.050

Li, Z., \& Cui, Y. (2017). Performance Evaluation Analysis of Chinese New Energy listed companies based on EVA.

Ma, Y. (2017). Comprehensive performance Evaluation and suggestion of Chinese Press and publication listed companies under the New normal condition.

Song, L., \& Jin, S. (2015). Production performance evaluation based on rough set theory and wavelet neural network. https://doi.org/10.3233/IFS-151943

You, P., Guo, S., Zhao, H., \& Zhao, H. (2017). Operation performance evaluation of power grid enterprise using a hybrid bwm-topsis method. https://doi.org/10.3390/su9122329

Zhang R. (2015). On the performance Evaluation of Enterprises with the combination of procedural rationality and result rationality in the New normal.

Zhang, B. (2016). Construction and demonstration of performance Evaluation system of New third Board. https://doi.org/10.13546/j.cnki.tjyjc.2016.24.049

\section{Copyrights}

Copyright for this article is retained by the author(s), with first publication rights granted to the journal.

This is an open-access article distributed under the terms and conditions of the Creative Commons Attribution license (http://creativecommons.org/licenses/by/4.0/). 